\title{
Protagonismo da mulher em cena, análise do espetáculo Acuados, coreografia-denúncia
} Acuados (Intimidated), denouncement choreography: gestures of violence against women

Suzane Weber Silva ${ }^{1}$ 


\section{Resumo}

Este artigo visa abordar alguns conceitos de feminismo e de gênero no Brasil, país onde o patriarcado é central no apoio à maioria das desigualdades e opressões sofridas pelas mulheres sobretudo no âmbito privado. $O$ artigo também exalta $O$ protagonismo da mulher nas artes cênicas, tendo como foco principal a trajetória artística da coreógrafa Eva Schul e sua atuação na dança e no teatro no Sul do Brasil. O artigo também apresenta uma análise da coreografia Acuados com direção de Eva Schul. Trata-se de uma coreografia-denúncia produzida para celebrar os vinte cinco anos da Ânima Cia de Dança e marcar os dez anos da lei brasileira Maria da Penha. Os aspectos de opressão vividos pelas mulheres no âmbito doméstico são descritos aqui a partir da coreografia Acuados entremeados a luz de um olhar feminista.

Palavras-chave: Feminismo; coreografia; violência contra a mulher; patriarcado; Eva Schul

\section{Abstract}

This article aims to approach some concepts of feminism and gender in Brazil, a country where patriarchy is central to supporting most of the inequality and oppression that women suffer, especially in the private sphere. The work also extols women's prominence in the performing arts and focuses mainly on the artistic career of the choreographer Eva Schul and her participation in dance and theater in South Brazil. It also presents an analysis of the choreography Acuados, directed by Eva Schul. This is a protest-choreography that was produced to celebrate the 25th anniversary of the dance company Ânima Cia de Dança and to mark the tenth anniversary of the Brazilian law Maria da Penha. The aspects of oppression experienced by women in the domestic sphere are described herein based on the choreography Acuados, interspersed with insights from a feminist perspective.

Keywords: Feminism; choreography; violence against women; patriarchy; Eva Schul 
Este artigo, em um primeiro momento, apresenta uma breve revisão do feminismo centrando em autoras brasileiras (Carneiro, 2015; Nogueira, 2001;) com o intuito de trazer à luz do debate o quanto as questões que envolvem o patriarcado estão em torno do espaço privado e do núcleo familiar. É nesse espaço social que ocorre grande parte da violência contra a mulher, contexto que a coreografia Acuados busca evidenciar.

Em um segundo momento, tendo em vista que, nos anos 1960, nas artes, e ainda hoje, sobretudo no teatro, a visibilidade creditada aos atores e diretores homens era e ainda é uma forte tendência, buscamos, dentro das artes cênicas, exemplos de narrativas femininas entrelaçadas ao contexto feminista desse período. Para isso, pontuamos alguns exemplos de mulheres artistas situadas entre a dança, o teatro e a performance, sublinhadas por RoseLee Goldberg e Marvin Carlson. Esses autores evidenciam o início de narrativas autobiográficas femininas, ou temáticas feministas e, ainda, criações artísticas notáveis assinadas por mulheres no contexto feminista da década de sessenta, principalmente na cena da América do Norte. Visando a destacar contribuições de mulheres artistas nas artes cênicas no Brasil nesse mesmo período, trazemos neste artigo, um exemplo brasileiro que simboliza um marco de representação do corpo da mulher. Essa virada, protagonizada por uma atriz - Tônia Carrero, revisitada na obra de Joana Tavares (2010), dá-se pelo discurso do corpo, tanto em termos de representação de classe social, quanto pela ousadia de gestos trabalhados a partir de um preparo corporal no momento do processo - o que na época era algo inédito. A entrada da preparação corporal no teatro, a partir dos anos 1960, do qual a família Vianna no Brasil é grande referência, denota uma virada nas artes cênicas. Trata-se da procura de uma fisicalidade, no que se refere à representação do corpo, e aí podemos reposicionar certas contribuições das mulheres.

$\mathrm{Na}$ continuidade do artigo, apresentamos um breve histórico da coreógrafa Eva Schul enquanto artista e mulher que viveu as utopias de seu tempo e quebrou barreiras numa sociedade tradicional no sul do país. Por fim, temos uma análise da coreografia Acuados, a fim de compreender o discurso do corpo que está por trás dos giros e saltos. Acredito ser fundamental posicionar a dança, enquanto uma arte que se exprime numa linguagem não verbal, em torno das reflexões das ciências sociais utilizando autoras renomadas de pesquisas no Brasil, tais como a antropóloga Berenice Bento, nos estudos de gênero, e a socióloga Rita Segato nos estudos feministas. Parte do referencial teórico neste artigo insere-se dentro do contexto das artes cênicas a partir de um olhar do ponto de vista de análise de práticas corporais. No entanto, outra parte, advinda das ciências sociais, são referenciais que contribuem com reflexões e conceitos de modo a desmascarar e romper com certos sexismos e hierarquias da cena e seus processos. Por fim, no que se refere à análise coreográfica, acredito que, além dos aportes teóricos, minha experiência enquanto artista, bailarina e professora de teatro, no coração das práticas no âmbito das artes cênicas, permeia meu olhar de pesquisadora de modo a perscrutar a análise do discurso do corpo no amálgama entre prática e teoria. 


\section{O feminismo entre os movimentos contestatórios da modernidade e da arte}

Entre os movimentos contestatórios modernos, o feminismo - enquanto fenômeno social e cultural - pode ser considerado como um daqueles momentos que ofereceu para a História um novo ponto de vista para além de impactos históricos, uma vez que acarretou efeitos simbólicos e práticos na organização da vida pública e privada e seus possíveis desdobramentos na sociedade. De modo geral, são reconhecidas três balizas como ondas desse fenômeno, que assume versões específicas de acordo com lugar e com os sujeitos que dele decorrem.

A primeira onda do feminismo é normalmente apontada no século XIX, associada à mulher na esfera púbica, à sua reivindicação de igualdade e à busca por melhores condições de trabalho. Essa primeira onda ${ }^{2}$ ficou conhecida como o Movimento Sufragista, cuja sua principal reivindicação foi o acesso da mulher ao estatuto de "sujeito jurídico" por meio do voto (Nogueira, 2001). Consequências desse movimento verificaram-se no século seguinte, com a conquista pelo direito de voto das mulheres (Nova Zelândia, 1893; Reino Unido, 1918; EUA, 1919; Brasil, 1932).

A segunda onda do feminismo, situa-se na década de 1960 e prolonga-se por duas décadas, em que a consciência da opressão sobre as mulheres emerge não mais somente nas questões relacionadas à vida pública e ao trabalho, mas essencialmente no seio da família nuclear. A partir dos anos 60, o pensamento feminista percebe 0 quanto a mulher figura como dependente, subvalorizada e, frequentemente, isolada da sociedade, confinada à dedicação ao lar.

O criticismo feminista sobre a ideologia prevalecente da existência da família nuclear como uma instituição imutável, natural e necessária, sugeria que esta (ideologia), representava apenas uma mera glorificação hipócrita da maternidade, que acarretava desigualdades de poder entre os membros de um casal. Assim, depois do ataque promovido pelas ativistas da segunda onda, as críticas à família como uma união sancionada pela lei e pela igreja, aceleraram de forma violenta. $\mathrm{O}$ número de pessoas que questionavam o valor do casamento como uma instituição, a formalização do amor, assim como as questões parentais, foi sendo cada vez maior. Em muitos países, a legislação não acompanhou estes desafios e as reivindicações consequentes (divórcio, por exemplo), o que veio a dar origem a muitos conflitos. (Nogueira, 2001, p. 6)

A segunda onda, conforme Carneiro (2015) é caracterizada pela crítica ao etnocentrismo, pelas lutas por direitos civis e lutas anticolonialistas. Na América do Norte e na Europa, emergem as feministas negras, entre as quais destacam-se Ângela Davis e Alice Walker. A partir dos anos 80, pontua-se um pensamento social em direção a "uma radicalização da crítica ao racionalismo essencialista e às categorias da identidade, particularmente sexo-gênero, raça-etnia e classe social" (Carneiro, 2015, p. 245).

O livro da filósofa Simone de Beauvoir O Segundo Sexo (1949) questiona a prerrogativa biológica da diferença sexual e a destinação sociocultural das mulheres: "Não se nasce mulher, torna-se mulher". Essa afirmação é largamente difundida a partir da segunda onda do feminismo. Ainda nos anos 80 , os estudos de gênero

${ }^{2}$ Carneiro (2015) aponta que uma das balizas históricas que informa o feminismo data de 1792, feita na Inglaterra por Mary Wollstonecraft através da Reivindicação dos Direitos da Mulher (Vindication of The Rights of Woman). 
abraçam um campo de pesquisas interdisciplinares. Influenciada por Michel Foucault, a historiadora Joan Scott procura descontruir a oposição universal entre as categorias homem e mulher, masculino e feminino. Outro nome de destaque é a filósofa Judith Butler, que problematiza a dissolução da dicotomia sexo-gênero (natureza-cultura). Seus estudos abrem caminho para diferentes epistemologias feministas e para a elaboração de pensamentos tais como os estudos Queer e os Movimentos LGBT. No Brasil, vemos a proliferação de grupos de estudos, publicações especializadas, consolidação de espaços de debates e ações, como o Conselho Nacional de Direitos a Mulher (1985) e a Secretaria de Políticas das Mulheres no Governo Federal (2003). São evidências da atuação das mulheres e da sociedade organizada em lutas em prol das mulheres, na busca de transformações sociais na esfera do trabalho, da saúde, da cultura e cidadania.

Ao mesmo tempo, no final da década de 80, Nogueira (2001) aponta que o feminismo, em certos contextos, parece ter ficado "fora de moda". Um dos motivos para isso foram as informações difundidas pelas mídias de comunicação sociais, as quais buscaram bombardear as conquistas feministas através de distorções de dados e de notícias. Nogueira (2001) comenta que a frase usual ouvida nos últimos anos - "Eu sou feminista, mas ..." -, na verdade, reflete o pensamento de mulheres que sentem a desigualdade sexual, mas rejeitam a imagem convencional do feminismo divulgada pelas mídias. Para a autora, essa situação está associada ao aparecimento do backlash norte-americano, num movimento de reação contrário ao feminismo que surgiu a partir dos anos 1970. A jornalista americana Susan Faludi ficou conhecida com o livro "Backlash: o contra-ataque na guerra não declarada contra as mulheres" (1991), obra que analisa a onda conservadora que buscou destruir as conquistas feministas da década de 1970. Assim, os anos 80 foram povoados de mitos que culpavam o feminismo por uma suposta infelicidade das mulheres americanas. Algumas palavras-chaves para a segunda onda do feminismo, tais como autonomia, autodeterminação e independência econômica, tornaram-se, na visão conservadora, um fardo para mulheres que acumulavam funções em casa.

O discurso tradicional e patriarcal norte-americano, por um certo tempo, vendeu a tese, segundo a qual, ser feminista era ser mal amada, era ser uma mulher desinteressante do ponto de vista do desejo, problemática, cansada, "sapatona" etc. O fato de muitas mulheres dizerem "sou feminista, mas..." representa a tentativa de se afastar de estereótipos veiculados por uma discreta, mas eficiente ideologia tradicional, patriarcal ${ }^{3}$, na tentativa de inviabilizar e destruir o movimento feminista enquanto coletivo. Essa é apenas uma das razões para designar-se a terceira onda do feminismo de pós-feminismo.

Nos últimos anos, no Brasil, algumas mulheres, vítimas de algum tipo de abuso, estupro ou violação têm sido depreciadas nas mídias por beberem demais, mostrarem o corpo exageradamente, saírem à rua "na hora que não deveriam" etc. Em muitos casos, a mídia e o senso comum, em vez de responsabilizarem a cultura machista pela violência sexista dos homens, acabam por responsabilizar a vítima. Em resposta

\footnotetext{
${ }^{3}$ A palavra patriarcado se origina da combinação de duas palavras pater (pai) e arke (origem, comando). A expressão refere-se as organizações familiares e sociais em que o homem, o patriarca, submete os outros membros da família ao seu poder. Ver Colling, A. M. e Tadeschi, L. A. (2015).
} 
a esse retrocesso, blogueiras brasileiras ${ }^{4}$ feministas buscam divulgar, contrapor e explicar seus posicionamentos nas redes sociais com "manifestos" feministas difundidos a partir de provérbios tais como como "meu corpo, minhas regras", "vestida ou pelada, quero ser respeitada", "minha roupa não é convite" etc. Fotos de mulheres, nas redes sociais, com cartazes com essas mensagens são resultados de movimentos sociais que buscam enfrentar a onda de conservadorismo no mundo todo, fato que pode ser evidenciado pela tomada de poder por líderes de direita ou conservadores na América. Por isso, mais do que nunca vivemos um momento que é preciso revelar o quanto as mulheres precisam lutar por seus direitos na luta contra o sexismo.

Nesse sentido, quando Eva Schul e a Ânima Cia de Dança, no ano de 2016 levam a público a obra Acuados como uma coreografia-denúncia, o grupo apela à dança para reiterar o quanto ainda é necessário que haja mudanças sociais para se garantirem os direitos femininos frente à opressão e à forte violência sofrida entre as quatro paredes do espaço privado e no seio da família nuclear.

\section{Movimento feminista e protagonismo das mulheres nas artes}

Para compreender o movimento feminista pelo viés das artes, cabe destacar a importância da performance e sua influência no teatro e na dança nas últimas décadas. É no final dos anos 70, nos Estados Unidos, que a historiadora sul-africana RoseLee Goldberg ${ }^{5}$ escreve o principal livro sobre a "performance art", em cujo prefácio a autora sintetiza a performance como uma arte para aqueles que procuram um caminho de quebra de categorias. Goldenberg (2007) destaca o protagonismo de artistas mulheres, tais como as artistas Yvonne Rainer, Carolle Schneemann, Trisha Brown $^{6}$, e ainda várias performers associadas com a Judson Dance Theater ${ }^{7}$, movimento que Eva Schul vivenciou em Nova York, em suas inúmeras estadas na cidade.

Marvin Carlson $(2010)$ e Sally Bannes $(1987,2003)$ destacam que é com o advento da performance invadindo a cena da dança e do teatro que começamos a ver um maior espaço para as questões que envolvem identidades imbricadas em discursos autobiográficos femininos. Os autores evidenciam certas transformações que, a partir dos anos 90, na performance e na improvisação em dança nos Estados Unidos, indicam um afastamento de questões estético-formais para uma maior exploração de discursos de certos grupos invisibilizados ou excluídos, abordando questões associadas a questões de classe, de gênero ou raça. Carlson (2010) aponta que um estudo importante sobre a arte da performance das mulheres, nos anos 1970, trata-se

\footnotetext{
${ }^{4}$ Entre os exemplos das blogueiras feministas brasileiras que ganharam destaque nas redes sociais, estão: Clara Averbuck (Lugar de Mulher), Djamila Ribeiro, Helena Dias (Azmina), Juliana de Faria (Think Olga), Sofia Soter (Capitolina) e também Coletivo Blogueiras Negras, entre outras.

${ }^{5}$ RoseLee Goldberg nasceu em Durban, na África do Sul. Ela estudou Ciência Política e Belas Artes na Universidade de Wits, em Joanesburgo. Em 1975, estabeleceu-se em Nova York. Em 1978, tornou-se curadora do espaço de vanguarda Kitchen. Sua principal obra, em sua primeira edição, data de 1979, Performance Art: From Futurism to the Present da editora inglesa Thames and Hudson.

${ }^{6}$ Thrisha Brown (1936-2017) bailarina e coreógrafa americana. Participou ativamente do movimento da Judson Church e do nascimento da dança pós-moderna. Entre suas obras destacam se coreografias, performances na rua e happenings. Parte de seu trabalho coreográfico é a partir do estudo do espaço, acumulação de movimentos e estudos do peso do corpo. Tem inúmeras colaborações com grandes nomes de sua geração como Steve Paxton, Yvone Rainer, Lucinda Childs, entre outros. Ver Bannes (2003).

${ }^{7}$ Judson Dance Theater é um atelier situado em uma igreja do Washington Square em Nova York que acaba por dar nome a uma corrente artística dos anos 60 associada sobretudo à dança. Essa corrente é considerada fundadora da dança pós-moderna. Entre os artistas que participavam desse grupo encontramos Yvone Rainer, Steve Paxton, Thrisha Brown, Lucinda Childs, Debora Hay, Robert Rauschenber, Meredith Monk, entre outros.
} 
da obra The Amazing Decade (A incrivel década) de Moira Roth. Para Roth (apud Carlson, 2010), as performances feministas podiam seguir três orientações: performance relacionada à experiência pessoal das mulheres; performance relacionada ao passado coletivo das mulheres; performance relacionada à exploração de estratégias de ativismo feminista. Com relação ao primeiro tipo, Carlson (2010) destaca o quanto a temática a partir de experiências das mulheres pode ser emblemática e o disparador para a criação na arte da performance. A diversidade de reivindicações feministas que caracterizam a segunda onda do feminismo reflete a multiplicidade de manifestações artísticas por parte das mulheres. O refrão "o pessoal é político" manifesta que um dos principais temas de libertação das mulheres ocorre na esfera do privado.

No Brasil, em termos de artes cênicas, um marco de virada em termos de representação do corpo da mulher data do final dos 1960 com a estreia da peça Navalha na Carne ${ }^{8}$, de Plínio Marcos, com direção de Fauzi Arap. Com um desempenho histórico e aclamada pela crítica, a atriz Tônia Carrero (1922-2018), no papel da prostituta Neusa Sueli, ganhou inúmeros prêmios. A peça é um retrato do submundo brasileiro, em que tipos como cafetão, homossexual e prostituta - todos de origem pobre - entoavam gírias e se apresentavam em cenas de violência. A peça representa uma virada que marca o teatro brasileiro com tipos muito pouco representados na época. O desempenho de Tônia Carrero, atriz que (até então) não passava de um belo rosto e que promovia comerciais de creme de beleza nas revistas da época, ganhou notoriedade a partir dessa peça. Na peça de Plínio Marcos, ela aparece em cima da cama, de cócoras, joelhos a mostra, discutindo com o (personagem) Vado, seu cafetão na narrativa do drama. O elenco teve a preparação corporal de Klauss Vianna9, algo inusitado naquele período. Como destaca Joana Tavares (2010), a partir do momento em que a presença do coreógrafo no teatro se desvincula da marcação de coreografia ou "dancinhas" 10 , algo novo estava ocorrendo no teatro brasileiro. Um outro dado importante é que, assim como Klaus Vianna tem no teatro um papel precursor relacionado ao trabalho corporal para atores - e a peça citada é exemplo disso - no sul do país Eva Schul ocupa esse mesmo pioneirismo. Entre os anos 70 e 80, ela trabalhou a preparação corporal de atrizes e atores, colaborando ao lado de inúmeros diretores de teatro tais como Antônio Carlos Kraide, Marcelo Marchioro, Celso Nunes e Luiz Arthur Nunes, entre outros.

Ainda que essa peça citada não esteja associada a um teatro feminista, certamente ela marca a mudança de representação da imagem da mulher na cena teatral brasileira. O fato de uma das atrizes mais atuantes do teatro brasileiro, como Tônia Carrero, aparecer em plena ditadura da década de 1960 em atitudes e ações não

\footnotetext{
${ }^{8}$ A peça Navalha na carne seria apresentada no Rio de Janeiro em 1967, mas foi proibida pela censura nesse ano. Ainda em1967, em plena ditadura Tônia Carreiro lutou para conseguir liberar a peça de Plínio Marcos, um texto carregado de palavrões em uma época onde tudo era censurado. A atriz conseguiu a liberação da peça, e enfim a peça teve sua estreia em São Paulo com a direção de Fauzi Arap, os atores Tônia Carrero (Neusa Sueli), Emiliano Queiroz (Veludo) e Nelson Xavier (Vado) e preparação corporal de Klauss Vianna. Tônia Carrero com essa peça dá uma virada em sua carreira ao se entregar a uma personagem dramática e de classe social desfavorecida.

${ }^{9}$ Os bailarinos mineiros Klauss Vianna (1928-1992) e Angel Vianna (1928) são precursores do trabalho de preparação corporal no teatro. Iniciaram a parceria profissional nos anos 1950 e casaram-se em 1955. Rainer Vianna, o único filho do casal, nasceu em 1958 e faleceu em 1995. Foi o primeiro a sistematizar o método desenvolvido pelos pais. As abordagens corporais desenvolvidas por Vianna podem ser visitadas através de seus acervos. Ver: Acervo Klauss Vianna (http://www.klaussvianna.art.br/) e Acervo: Angel Vianna (http://www.angelvianna.art.br/). Ver também: Tavares (2010).
}

${ }^{10}$ Estamos tratando aqui de um teatro que não é aquele associado a musicais ou teatro de revista onde é previsto coreografias. 
glamorosas, marca a coragem e a importância de mudança de paradigma de representação do corpo da mulher.

\begin{abstract}
"Quando a atriz Tônia Carrero sugeriu, durante os primeiros ensaios da peça, que o elenco deveria fazer um trabalho diário de corpo estava contribuindo, de certo modo, para a formação de uma nova prática no teatro carioca: a "preparação corporal" do ator. Uma função que nasceu do desejo de uma atriz pelo controle do seu próprio corpo, mas que precisou do reconhecimento e da aceitação de um diretor para vigorar. (Tavares, 2010, p. 95)
\end{abstract}

De lá para cá, encontramos, hoje, um espaço de representação da mulher brasileira razoavelmente diversificado nas artes cênicas, tanto no teatro, quanto na dança e na performance cênica. Mas não só isso, a mulher cada vez mais atua em áreas anteriormente ocupadas por homens como a direção e a produção. A presença de diretoras mulheres ${ }^{11}$ nos festivais de artes cênicas é notável. $E$, para citar um exemplo de grande prestígio, Christine Jatahy é uma das diretoras brasileiras de teatro das mais requisitadas nos festivais internacionais, além de receber inúmeras boas críticas em jornais no exterior. No entanto, a reivindicação de uma maior visibilidade de mulheres artistas negras no Brasil indica um espaço - ainda - de desigualdade nas artes cênicas brasileira e mostra o quanto ainda temos que avançar em termos de diversidade étnico-racial. E mais, é Lúcia Romano $(2009,2013)$ quem nos alerta sobre a ficção que permeia as práticas das artes cênicas sobre a neutralidade de gênero e suas consequências na preparação corporal em teatro. As pesquisas da autora, de longa data, denunciam o sexismo que impera nas artes cênicas, baseado em uma universalidade do corpo, subtendido pela noção de neutralidade. Segundo a autora, para pensar as práticas corporais para a cena, de modo a romper com a cegueira de gênero nas variantes racial, social e étnica, faz-se necessário sair do paradigma de corpo universal, alijado de sua história cultural e individual, para promover o corpo subjetivado. Assim, as experiências das mulheres atrizes, bailarinas e performers, incluindo corporeidades híbridas, podem sair do silêncio para serem debatidas e reposicionadas, como é o caso do exemplo citado de Tônia Carrero.

\title{
Eva Schul, rebeldia e protagonismo na dança no sul do país
}

Eva Schul ${ }^{12}$ é coreógrafa, professora de dança e diretora da Ânima Cia. de Dança, sediada em Porto Alegre. Ela iniciou seus estudos de balé em Porto Alegre na escola de Maria Júlia da Rocha entre o período de 1956 a 1964. Suas primeiras referências de dança moderna no Brasil foram a partir de sua participação no I Congresso de Dança Brasileiro, realizado em Curitiba, em 1963, onde, aos 15 anos, Eva Schul

\footnotetext{
${ }^{11}$ Exemplos de diretoras de teatro e ou dança que se destacam no Brasil: Beth Lopes (RS), Patrícia Fagundes (RS), Adriane Mottola (RS), Carlota Albulquerque (RS), Neyde Veneziano (SP), Cibele Forjaz (SP), Lúcia Romano (SP), Maria Thais, Bia Lessa (SP), Graziela Rodrigues (RJ), Luciana Lyra (PE), Grace Passô (MG), entre outras.

${ }^{12}$ Eva Schul, filha de judeus húngaros, nasceu em 3 de fevereiro 1948 em Cremona (Itália) num campo de refugiados; era criança quando sua família chegou ao Brasil, estabelecendo-se em Porto Alegre. Sobre sua obra, ver documentário da série Figuras da Dança, da São Paulo Companhia de Dança (2016). Em 2009, Eva Schul e Mônica Dantas propuseram o projeto Dar Carne à Memória contemplado com o prêmio Klauss Vianna 2009, que recriou parte do repertório coreográfico de Eva Schul (Dantas, 2011).
} 
conheceu Nina Verchinina ${ }^{13}$. Na juventude, leu precocemente O Segundo Sexo, de Simone de Beauvoir (1949), presente dado por sua mãe. Essa leitura não passou despercebida pelas mães de suas colegas, que reprovaram a leitura da colega de suas filhas, segundo conta Eva Schul em palestra ${ }^{14}$ ministrada em 2018 (Schul, 2018a). Em 1964, aos 16 anos, Eva Schul viaja para os Estados Unidos para realizar um estágio no New York City Ballet. No seu retorno, Eva volta a estudar ballet com Tony Petzhold (1914-2000) e ingressa no curso de Graduação em Artes Visuais, no Instituto de Artes da Universidade Federal do Rio Grande do Sul (UFRGS), o qual não conclui. Faltando um ano para se formar, insatisfeita com o balé e também com a formação acadêmica em artes visuais, embalada pelo ar hippie da época, decide viver em uma comunidade rural autossustentável no interior do Rio Grande do Sul, experiência que não dura muito tempo. Sua atitude de viver em comunidade mostra o quanto Eva estava conectada com as utopias do seu tempo (Dantas, 2013). Depois dessa experiência, volta para os estudos em dança e, em 1975, com a vinda a Porto Alegre do Nikolais Dance Theatre, Eva conhece Alwin Nikolais (1910-1993) que a estimula a estudar dança moderna em Nova York. Eva Schul dedica grandes temporadas em Nova York para estudar não somente com Alwin Nicolais, mas, sobretudo, com Hanya Holm. Ela também frequenta a escola de Marta Graham, Merce Cunningham e discípulos de Jose Limón; estuda com Phyllis Lahmut improvisação e composição; e, aprende com Irmgard Bartenieff, os princípios de análise do movimento de Rudolf Laban. Segundo Eva Schul (2018), suas estadas em Nova York, nesse período, também foram uma oportunidade de acompanhar o nascimento da dança pós-moderna, bem como toda a combustão da cena cultural daquele período, por meio de happenings, performances e eventos de arte (Dantas, 2013). Casa-se aos 19 anos e tem o primeiro filho com 21 anos; também esteve entre as primeiras mulheres a divorciar-se em Porto Alegre, o que comprova seu caráter de autonomia e emancipação de modo precoce. Como destaca Dantas (2012;2013), na primeira metade do século XX, momento em que a dança cênica se estabelece no Rio Grande do Sul, as referências clássicas e modernas entrelaçavam-se nos bailados das escolas, tais como as de Lya Bastian Meyer e Tony Petzhold. Conservando a hegemonia do balé, as escolas apresentavam coreografias com certa influência expressionista. Nesse sentido, a criação, em 1976, do Espaço e Grupo Mudança por Eva Schul representa um marco na cidade. Entre idas e vindas ao Brasil, ela consegue criar esse grupo e escola que reúne uma nata de artistas de todas as áreas em um espaço para a experimentação das artes e do movimento, bem como para o ensino de técnicas modernas de dança e improvisação.

No percurso artístico de Eva Schul, é importante destacar sua relação com o teatro em Curitiba, no final dos anos 70, e também sua forte atuação no início da Escola de Dança e no Curso Livre, ambos do Teatro Guaíra. Desde então, ela constitui uma

\footnotetext{
${ }^{13}$ Nina Verchinina bailarina, coreógrafa e pedagoga na área da dança nasceu na Rússia em 1910 e morreu em 1995 na cidade do Rio de Janeiro. Viiveu em muitos países da Europa, das Américas e da Oceania. Em 1945 fixa residência no Brasil a partir do convite da bailarina Tatiana Leskova (1922). É considerada uma das mais importantes pioneiras da dança moderna no Brasil.

${ }^{14}$ Lançamento do Projeto Carne Digital: Arquivo Eva Schul sob coordenação das professoras Mônica Dantas e Suzane Weber da Silva em 18 de setembro de 2018 na Salão de Festas da Reitoria da UFRGS. O projeto tem por meta o desenvolvimento de arquivos digitais em artes cênicas que fomentem o registro, a documentação, a reflexão crítica e a difusão de obras e eventos em artes cênicas. Nesse primeiro momento, o projeto se concentra sobre os arquivos de Eva Schul e consequentemente os inúmeros artistas que colaboraram com sua obra. Esses arquivos, os quais estou diretamente envolvida conta com programas, entrevistas e inúmeros documentos os quais tenho tido acesso e me auxiliaram na escrita desse artigo.
} 
enorme carreira de produção em teatro e dança, enquanto bailarina, mas sobretudo como professora e coreógrafa, tendo ainda algumas passagens como gestora. Eva se estabeleceu em Curitiba, nos anos 80, onde teve duas filhas. Em 1990, voltou a Porto Alegre e criou o grupo Ânima Companhia de Dança, com o qual monta inúmeras obras e reúne bailarinos de formações diversificadas. Eva Schul mantém sua marca na companhia, que é a participação intensa de colaboração dos bailarinos em seus processos de criação. Em 2018, com 70 anos, ela completa 55 anos de carreira e acumula inúmeros prêmios ${ }^{15}$ de dança. Alguns poucos dados de sua carreira, citados aqui, servem para mostrar o seu protagonismo (desde a sua juventude) nas artes, assim como sua condição de mulher independente, profissional e pioneira no ensino da dança moderna no sul do país.

A coreografia Acuados ${ }^{16}$, assinada por Eva Schul e produzida pela Ânima Companhia de Dança, teve sua estreia em 14 de junho de 2016 e marca os 25 anos da companhia. Segundo a coreógrafa e, conforme se encontra no programa, Acuados trata-se de uma coreografia-denúncia que comemora os dez anos da lei popularmente conhecida como Maria da Penha ${ }^{17}$. O que faz a coreografia Acuados (2016) poder ser vista sob as lentes de um teatro feminista, performance feminista ou pós-feminista? Como afirma Eva Schul em depoimentos de alguns documentários que relatam sua trajetória ${ }^{18}$, e conforme podemos acompanhar, acerca de suas viagens aos Estados Unidos e Argentina, vemos a busca de uma formação sólida na arte contemporânea e engajamento com as questões do seu tempo. De modo coerente com a cronologia de suas obras, ela é uma mulher que assume falar a partir do seu ponto de vista de mulher e a partir de sua condição precocemente independe, tendo em vista que com dezesseis anos, crescida em uma família de classe média, já estava fora do país em busca de uma formação artística que pudesse corresponder aos seus anseios artísticos. Nesse sentido, acredito que refletir sobre um teatro feminista é conceber o teatro a partir do ponto de vista das mulheres e de seus discursos contestatórios em direção à opressão por elas sofridas na sociedade. Acredito, também, que reconhecer a importância desse ponto de vista é algo recente, pois ainda é emergente a nova historiografia sob a influência do feminismo. Faz algumas poucas décadas que se evidenciou o quanto a dominação masculina, em quase todos os setores da sociedade, impôs às mulheres a invisibilidade, o silêncio e o confinamento ao privado. Por isso, a história das mulheres é, antes de tudo, a história dos corpos das mulheres.

\footnotetext{
${ }^{15}$ Entre os inúmeros prêmios na área das artes cênicas recebidos por Eva Schul, destaca-se em 2015 a Medalha da Ordem Mérito Cultural do Ministério da Cultura, condecoração que Eva recebeu das mãos da presidente em exercício na época, Dilma Rousself.

${ }^{16}$ A peça Acuados foi contemplada pelo Concurso FRUMPROARTE de Porto Alegre no ano de 2015. Em 2016 cumpriu temporada em três momentos, duas vezes no Teatro Álvaro Moreira e na sala 209 (extinta Usina das Artes na Usina do Gazômetro). Em setembro de 2017 apresentou-se no Teatro São Pedro no Festival Internacional Porto Alegre em Cena. Em 2018 ganhou os seguintes editais: Edital SEDACTEL 26/2017 e Edital de Concurso "Pro cultura RS FAC. Informações fornecidas pela produtora do Ânima Cia de Dança, Luka Ibarra.

${ }^{17}$ A Lei no 11.340/2006 ou, como é popularmente conhecida, Lei Maria da Penha foi aprovada por unanimidade pelo Congresso Nacional e assinada em 7 de agosto de 2006 pelo presidente Luiz Inácio Lula da Silva. Essa lei tornou-se o principal instrumento legal para coibir e punir a violência doméstica praticada contra mulheres no Brasil.

${ }^{18} \mathrm{~A}$ trajetória de Eva Schul pode ser encontrada em vários documentários, gostaríamos de destacar três que utilizamos para esse artigo: $\mathrm{O}$ olhar na dança: Eva Schul. Direção Geral e Coord. de Pesquisa: Juana Miranda. Produtor executivo: Maurício Amaral. Coordenadora Administrativa: Valéria Marcondes. Brasília, DF: Chang: Gestão, Marketing e Produção, 2018. Disponível em: <http://www.oolharnadanca.com.br/>. Acesso em: 26 de setembro de 2018; FACES|TVE: Eva Schul. Apresentação: Lena Kurtz. Produção executiva: Siliva Dinelli. Edição e finalização: Álvaro Cardoso. Porto Alegre: TVE, 2016. Disponível em: <https://www. youtube.com/watch?v=2xokA5GJnJo>. Acesso em: 26 de setembro de 2018; FIGURAS da Dança: Eva Schul. Direção: Inês Bogéa. Produção: Marcio Branco. Realização: São Paulo Companhia de Dança. São Paulo: Ambrogi Produções Cinematográficas, 2013. 1 DVD.
} 


\section{As paredes de Acuados, compartimentos de violência}

Maria da Penha - esse é o nome da farmacêutica e mãe de três filhos que, em 1983, sofreu duas tentativas de assassinato por parte de seu marido. Na primeira tentativa, o agressor disparou um tiro, à queima-roupa, de espingarda enquanto ela dormia. O tiro a deixou paralítica da cintura para baixo. Poucos meses depois, ele fez outra tentativa sabotando o chuveiro elétrico, ele tentou eletrocutá-la. $O$ agressor foi julgado duas vezes e só foi punido pela lei após dezenove anos do ocorrido. Ainda assim, ficou preso por apenas dois anos. O caso teve repercussão internacional e, por conta disso, o Brasil foi condenado, pela Comissão Internacional de Direitos Humanos, por omissão em relação à violência contra a mulher. Em 2006, a lei Maria da Penha foi aprovada e, desde então, representa um marco na luta contra a agressão doméstica. Essa lei representa o maior instrumento legal de denúncia da violência corporal e simbólica em relação à mulher. No entanto, Acuados (2016) não conta a história da Maria da Penha, mas se utiliza do tema da violência doméstica como mote para a criação.

Os primeiros estudos para a versão de 2016 começaram em 2015, com os bailarinos Bianca Weber e Alexssander Vidateli, os dois com forte formação em dança contemporânea. Conforme entrevista com Eva Schul (2018b), em 2015 o grupo pesquisou estatísticas de violência contra mulher e também entrevistaram algumas mulheres vítimas de violência. Grande parte desse material foi levado para o processo de criação para o desenvolvimento das cenas.

A gente pensava que era muito menor (o grau de violência contra as mulheres). Mas, conforme a gente foi ver os números, a gente viu que era mais escancarado, e hoje a gente sabe que é absurdo o número de feminicídios e de relações abusivas, né? Porque a gente sabia de alguns dados com criança, sabia de alguns tipos de relações (de violência). Mas a gente foi ver que todas as relações podem ter um lado abusivo. Tem abusos psicológicos. E em relações de casais do mesmo sexo, tem relações abusivas também, em que parecia (eles) estarem protegidos por estarem em uma relação diferente. (Schul, 2018b)

A coreografia Acuados (2016) busca evidenciar a crueldade física investida sobre o corpo da mulher dentro do matrimônio e da família. O grupo, no início da criação, fez inúmeras pesquisas, consultou estatísticas e conversou com mulheres que sofreram abuso. A partir desses dados, começou o processo de criação, investindo principalmente em duos. A coreografia tem sido apresentada pela Ânima Cia de Dança desde $2016^{19}$ e, para essa obra, conta com um grupo de seis intérpretes-criadores ${ }^{20}$. São eles: Driko Oliveira, Bianca Weber Dias Weber, Emily Chagas, Everton Nunes, Fernanda Santos e Jackson Conceição. Segundo o programa do espetáculo Acuados, a coreografia comemorativa aos vinte e cinco anos da Ânima Cia de Dança tem como objetivo:

\footnotetext{
${ }^{19}$ Gostaria de agradecer a cedência do registro em vídeo da obra Acuados pela produtora Luka lbarra para fins de análise. Também tive acesso as fotos do criação Acuados. Assisti, três vezes o espetáculo, nas três diferentes temporadas oficiais onde a criação foi apresentada.

${ }^{20}$ No processo da criação, em 2015, fez parte o bailarino Alexsander Vidateli que não fez parte das apresentações para o público. Em uma das temporadas da Sala Álvaro Moreira, a bailarina Vitória Bemfica substitui a bailarina Bianca Weber que se encontrava grávida. Na época eu fazia aula de dança com a Eva Schul na Sala 209 na Usina do Gazômetro, onde a Ânima Companhia de dança ensaiava. Sendo assim, tive a oportunidade de acompanhar vários ensaios do início do processo. Assisti também uma mostra de processo que aconteceu aberta ao público nessa mesma sala. Nesse artigo, para a análise do espetáculo, tive acesso ao registo de vídeo realizado em dois teatros, no teatro Sala Alvaro Moreira e teatro São Pedro (UTZ, 2016).
} 
...ressaltar, denunciar e sensibilizar diferentes públicos para a questão da violência contra a mulher, especialmente no âmbito doméstico e os desdobramentos que esta violência gera na família e nas relações sociais dos envolvidos. (Schul, 2016)

Nos vinte e cinco anos da Ânima Cia de Dança, houve muitas montagens que tematizaram as dificuldades de relacionamentos, dos papéis sociais relacionados à família ou temas associados às mulheres. Segundo a coreógrafa:

Somos muitos felizes com o que fazemos e com o que conseguimos atingir com nossos discursos corporais. Acima de tudo, com os que conseguimos estabelecer com muitos tantos parceiros, ouvintes e novos agregados. Tristes por estarmos fazendo uma denúncia tão séria neste momento, e, apesar disto, felizes por termos a oportunidade de escancarar pelos nossos meios uma tragédia cotidiana do mundo em que vivemos. Sabemos que muitos não irão gostar e até mesmo (não) querer ver o que estamos tratando. (Schul, 2016)

Não é a primeira vez que a coreógrafa Eva Schul tematiza algo de cunho feminista. Em 1998, em São Paulo, num evento de dança realizado pela Secretaria Municipal de Cultura, Eva criou um embrião da coreografia numa versão realizada a partir do pedido do casal de bailarinos paulistas Ana Teixeira ${ }^{21}$ e Osmar Zampieri22. Segundo a entrevista com Eva Schul (2018), naquela versão a violência era menos explícita que na versão de grupo de 2016. No entanto, o tema trabalhado pelo casal Ana Teixeira e Osmar Zamperi já tratava de uma relação abusiva de violência contra a mulher. E é pelo fato de Eva Schul buscar revelar diferentes facetas das mulheres em diferentes obras, muitas circunscritas no âmago das relações humanas, que podemos pensá-la numa artista através das lentes do feminismo. No entanto, em Acuados essa opção é evidente, sobretudo porque se trata de denunciar a violência contra a mulher na sociedade atual desenhada no detalhe.

Ao começar o espetáculo Acuados, a primeira cena que vemos é um espaço dividido em três partes, com três paredes finas cortando o palco, deixando à mostra três espaços compartimentados, como três quartos ou três apartamentos. Em cada um dos três espaços quadrados há um casal e vemos apenas suas silhuetas, de frente para o público. Aos poucos, à medida que a cena se revela através da iluminação, descobrimos que cada mulher, em cada compartimento, encontra-se a alguns poucos passos atrás de cada homem. Já essa primeira imagem pode ser uma boa metáfora para refletir sobre a condição da mulher na sociedade, uma hierarquia explícita de status: o homem na frente, e a mulher circunscrita no espaço do privado, entre as paredes do lar.

O primeiro movimento corporal da cena parte das mulheres. Com as mãos relaxadas ao longo do corpo, elas levantam lentamente um dos braços em direção aos homens. Eles respondem ao gesto apenas com o olhar e um leve virar de ombros

\footnotetext{
${ }^{21}$ Ana Teixeira é gaúcha de Caxias do Sul. Atuou como bailarina, de 1989 a 2004, em companhias como Balé da Cidade de São Paulo (onde foi diretora artística assistente de 2003 a 2009) e Staats Theatre de Kassel, na Alemanha. Atualmente, é consultora de dança contemporânea da SESC TC e pesquisadora da Enciclopédia Itaú Cultural de Dança e PUC-SP.

${ }^{22}$ Osmar Zampieri dançou como bailarino profissional em 1989, na Cia. Cisne Negro, em SP. Integrou também a Cia. de Dança do Palácio das Artes-BH (MG), Ballet Stagium (SP) e o Balé da Cidade de São Paulo (SP). Em 2001, foi morar em Paris (França), onde fez estágios de dança contemporânea e atuou como bailarino do Staats Theater de Kassel (Alemanha). Em 2003, inicia sua pesquisa como intérprete-criador e videomaker, concentrando-se no registro de espetáculos de dança contemporânea. Atualmente dirige o Grupo Grua, junto com Jorge Garcia e Willy Helm. Ver http://grua.gr
} 
e retornam logo para frente, olhando de volta para o público. É como se cada casal não enxergasse a si próprio; as mulheres veem os homens pelas costas, à sua frente. Para elas mulheres, o contorno do corpo masculino, que está à frente de cada uma, recorta seus olhares para o mundo.

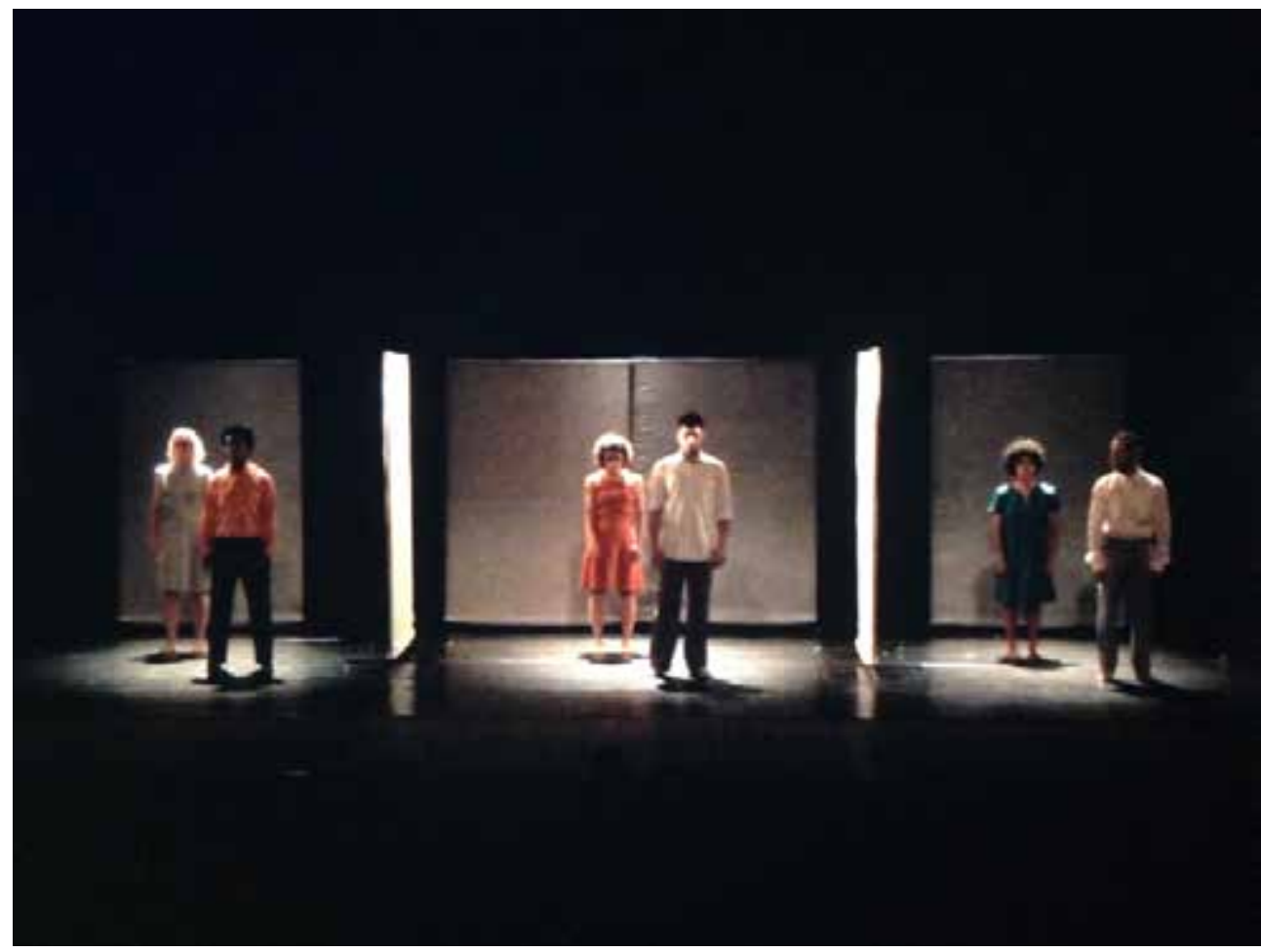

Abertura do espetáculo Acuados. Fotografia retirada do registro de vídeo. Foto: Natália Utz $(2016)^{23}$

Em cena, ao longo da coreografia, os bailarinos se organizam de diferentes formas. Na maior parte do tempo, eles se mostram como casais, mas há outras formações, como trios e quartetos, ou ainda algumas cenas de grupos. Nos primeiros deslocamentos corporais em cena, vemos vários jogos corporais de aproximação e de afastamento dos corpos; as mulheres tentando estar ao lado dos homens ou a sua frente. Mas é impossível, eles as detêm. Entre cada casal, as mulheres circulam em volta dos homens, como ioiôs. Ainda que os homens também se movam, eles estão mais fixos em seus lugares do que as mulheres no começo da coreografia. As mulheres afastam-se, aproximam-se, abaixam-se frente aos homens, são suspensas, há jogos de pesos dos corpos, e suspensões aparecem, mantendo a centralidade masculina. Eventualmente, ao afastarem-se dos homens, elas são pegas pelo cabelo, pelo pescoço, pelo pé. Os homens as trazem de volta para próximo deles ou ao centro de cena. Eles as sustentam corporalmente, as empurram, as carregam, as conduzem. Em algum momento, um homem tapa a boca de sua companheira. Ela abaixa a cabeça. Há breves momentos de carinho e também sensualidade junto às pequenas agressões. Ao som de uma ópera ${ }^{24}$ italiana, eles têm o controle e o poder.

\footnotetext{
${ }^{23}$ As fotos de Natália Utz (2016) nesse artigo são imagens printadas pela autora do artigo a partir da captação de vídeo da coreografia Acuados.

${ }^{24} \mathrm{Na}$ coreografia de Acuados há trechos de óperas italianas onde os momentos escolhidos são aqueles em que os cantores cantam frases de amor. Os trechos escolhidos são das seguintes opéras: La traviata (1852) e Tacea la notte plácida (1853) de Giuseppe Verdi; Voi che sapete (1786), Pordi Amor (1786) e A rainha da noite (1791) de Amadeus Mozart; Mio combino caro (1918) de Giacomo Puccini; Cruda sorte (1813) de Gioachino Rossini; Ebben ne andro Lontana (1892) de Alfredo Catalani.
} 
Em vários momentos, encontramos uma ironia entre o amor cantado na ópera e a violência das ações executadas pelos bailarinos. Há jogos de explicitação do poder masculino que ostentam desigualdades, assimetrias frente às mulheres: são jogos coreográficos que Acuados revela com primor. Trata-se do domínio de um discurso corporal articulado e de domínio técnico. A ironia dos gestos de opressão em relação aos versos da música, nos coloca uma questão: que amor é esse?

Na sociedade ocidental, ao longo da civilização, ao homem foi incentivado a "ir à luta", ganhar o mundo, enquanto a mulher deveria se satisfazer no espaço da casa, do lar. A primeira cena de Acuados, com os homens olhando a frente, posicionados à frente das mulheres, simboliza essa hierarquia de poder. Conforme a historiadora Mary Del Priore (2013), inúmeras culturas organizaram a diferença entre masculino e feminino de modo sempre hierarquizado, sobretudo depois do sacramento do matrimônio. Apesar das conquistas femininas ${ }^{25}$ e das mudanças das leis nas últimas décadas, o essencial no cotidiano brasileiro continua intocado: mulheres continuam a educar seus filhos, maridos não arrumam a cama, e filhos não lavam a louça (Del Priore, 2013). Para a socióloga Berenice Bento (2012), é na família que começam as divisões binárias das tarefas e funções segundo as diferenças sexuais. Essa estrutura com divisões binárias heteronormativas ${ }^{26}$ é sustentada pelas famílias tradicionais e faz parte de uma idealização idílica da família. Nesse sentido, os homens da obra Acuados têm seus atos repetidos, fabricados, performados, "macho mesmo", ou seja, a força, a truculência e, sobretudo, o controle aparecem em seus gestos enquanto masculinidade na lógica da heteronormatividade. Quanto às mulheres, os seus corpos fortes servem para responder, resistir e sobreviver a essa dominação, sempre num status de subordinação e subserviência, no paradoxo da força. Acuados explicita as sombras do lar, aquela realidade na qual os vizinhos pouco ousam se intrometer. Para Bento (2012), a noção de lar como sendo espaço de conforto espiritual, em muitos casos, não condiz com a realidade. Além de restringir a noção de família aos padrões da heterossexualidade, com papéis definidos e assimétricos, esses espaços são muitas vezes carregados de violências ao invés de cuidado e de proteção.

Um momento que corresponde a essa paisagem de violência doméstica é quando os bailarinos negros Emily Chagas e Jackson Conceição dançam em torno de uma mesa e duas cadeiras, simbolizando tipicamente o lar. Ao centro da cena, eles estão limitados por duas paredes, onde a cada lado do casal vemos "os vizinhos". Assim, nessa cena, temos três casais. O casal central atua em várias ações de opressão e de fuga, tendo as cadeiras e a mesa como suportes, trampolins de hierarquias, como um jogo de gato e rato. Ainda que a peça mostre os homens simbolizando o poder na maior parte do tempo, há pequenos momentos onde a mulher está "por cima".

\footnotetext{
${ }^{25}$ No Brasil, segundo Del Priore (2013), os anos 1970 e 1980 foram emblemáticos, pois um grande número de mulheres entrou para o mercado de trabalho; "elas tomaram pílulas anticoncepcionais" e "queimaram os sutiãs". Para a autora, essa revolução não ficou sem resposta, e o nível de violência contra as mulheres aumentou por conta de uma busca de um setor da sociedade pela manutenção do patriarcado.

${ }^{26}$ O conceito de heteronormatividade, cunhado em 1991 por Michael Warner, está associado ao conceito de heterossexualidade, que se sustenta na crença de que todos os sujeitos têm uma inclinação inata para eleger como objeto de desejo e parceiro de afetos alguém do sexo oposto, sendo esse um padrão da natureza. Dentro dessa perspectiva, a heterossexualidade é concebida como algo "natural", universal e normal. Consequentemente, outras formas de sexualidade são compreendidas como antinaturais, peculiares e anormais. Na heteronormatividade, entende-se que todos, heterossexuais ou não, devem organizar sua vida socialmente conforme o modelo "supostamente coerente" da heterossexualidade. As pessoas com genitália masculina devem se comportar como machos, másculos; e as pessoas com a genitália feminina devem ser femininas, delicadas; ou seja, na heteronormatividade há uma linearidade entre sexo e gênero.
} 
Exemplo disso, é os instantes onde a bailarina Emily Chagas fica em pé em cima da mesa, um momento de fôlego. Não dura muito esse momento de um certo poder. O que acontece é que, mesmo ela estando por cima, a mesa começa a ser inclinada. A mulher, Emily Chagas, que estava em cima, lentamente escorrega. Ou seja, mesmo quando ela está no poder, em pé em cima da mesa, pouco a pouco, ela vai perdendo status. Com o homem embaixo da mesa levantando um dos lados, a mesa se desestabiliza; é uma boa metáfora para representar as hierarquias estruturais de poder que estão a espreita para corroer as conquistas feministas. E os vizinhos, como testemunhas, não interferem, "em briga de marido e mulher não se mete a colher", diz o ditado popular.

Estatísticas de violência contra a mulher demonstram que ela sofre mais violência dentro das quatro paredes de casa do que em espaços públicos ${ }^{27}$. No Brasil, segundo essas estatísticas, uma mulher é espancada a cada 15 segundos. Conforme a Organização Mundial da Saúde, quase metade dos crimes de assassinato contra mulheres tem como autor o marido, o namorado ou o ex. O Brasil ocupa o quinto lugar no ranking de assassinatos contra as mulheres. Em se tratando de mulheres negras, a violência ainda é maior. Assim, a escolha coreográfica de investir em relações abusivas de casais heterossexuais está de acordo com o espaço no qual a mulher foi historicamente circunscrita, limitada e violentada. Os duos coreográficos representam a mulher nessa vida a dois, na qual ela vive a desigualdade de direitos, e é nesse sentido que a noção proposta por Eva Schul de "coreografia-denúncia" ganha força.

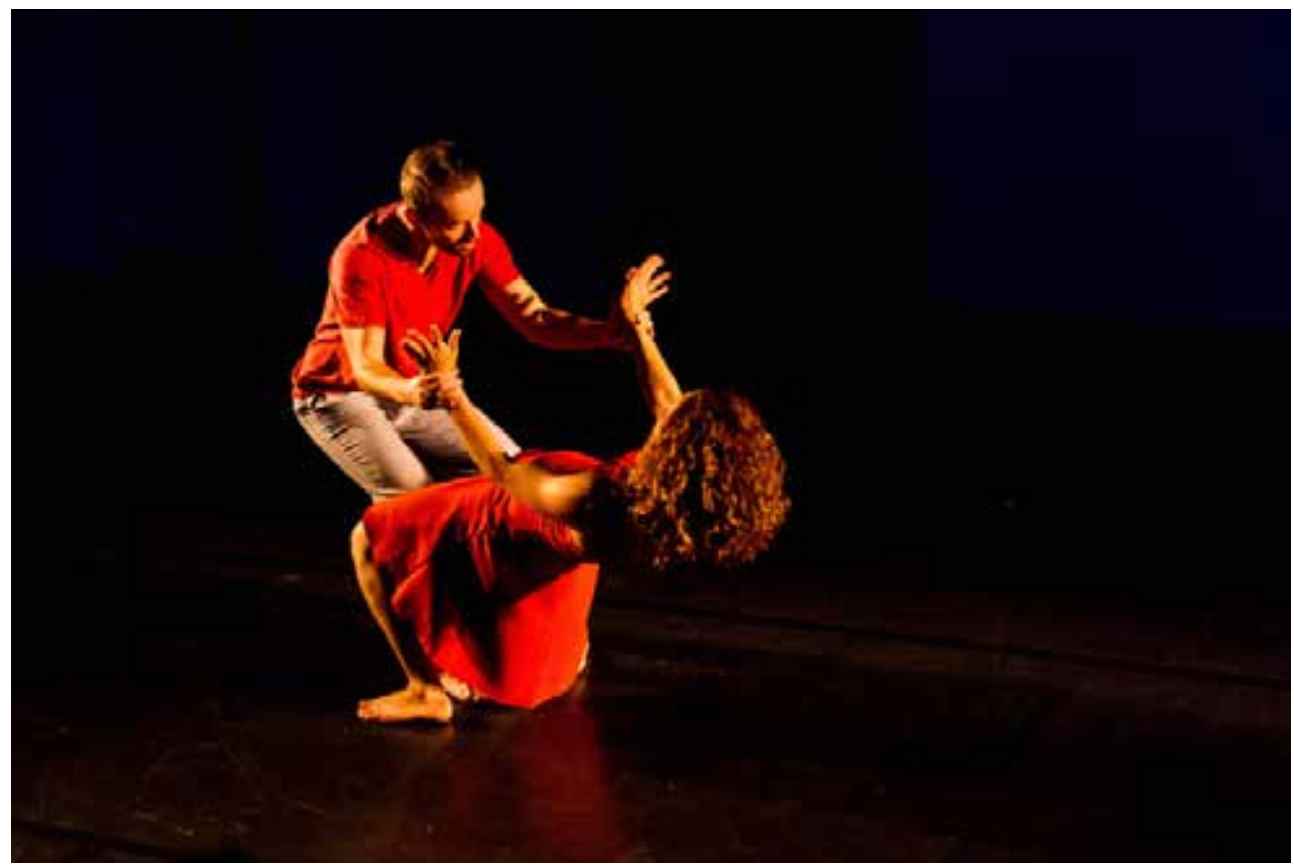

Everton Nunes e Fernanda Santos em Acuados. Foto: Raquel Basso

\footnotetext{
${ }^{27}$ No Brasil, o site intitulado "Compromisso e Atitude pela Lei Maria da Penha - A lei é mais forte" apresenta inúmeras estatísticas que envolvem a violência contra as mulheres. Esse site é resultado da cooperação entre o Poder Judiciário, o Ministério Público, a Defensoria Pública e o Governo Federal, por meio da Secretaria de Políticas para as Mulheres da Presidência da República e o Ministério da Justiça. Segundo o site, 98 \% das mulheres já ouviram falar da Lei Maria da Penha, e $70 \%$ das mulheres consideram que a mulher sofre mais violência em casa do que em espaços públicos.
} 


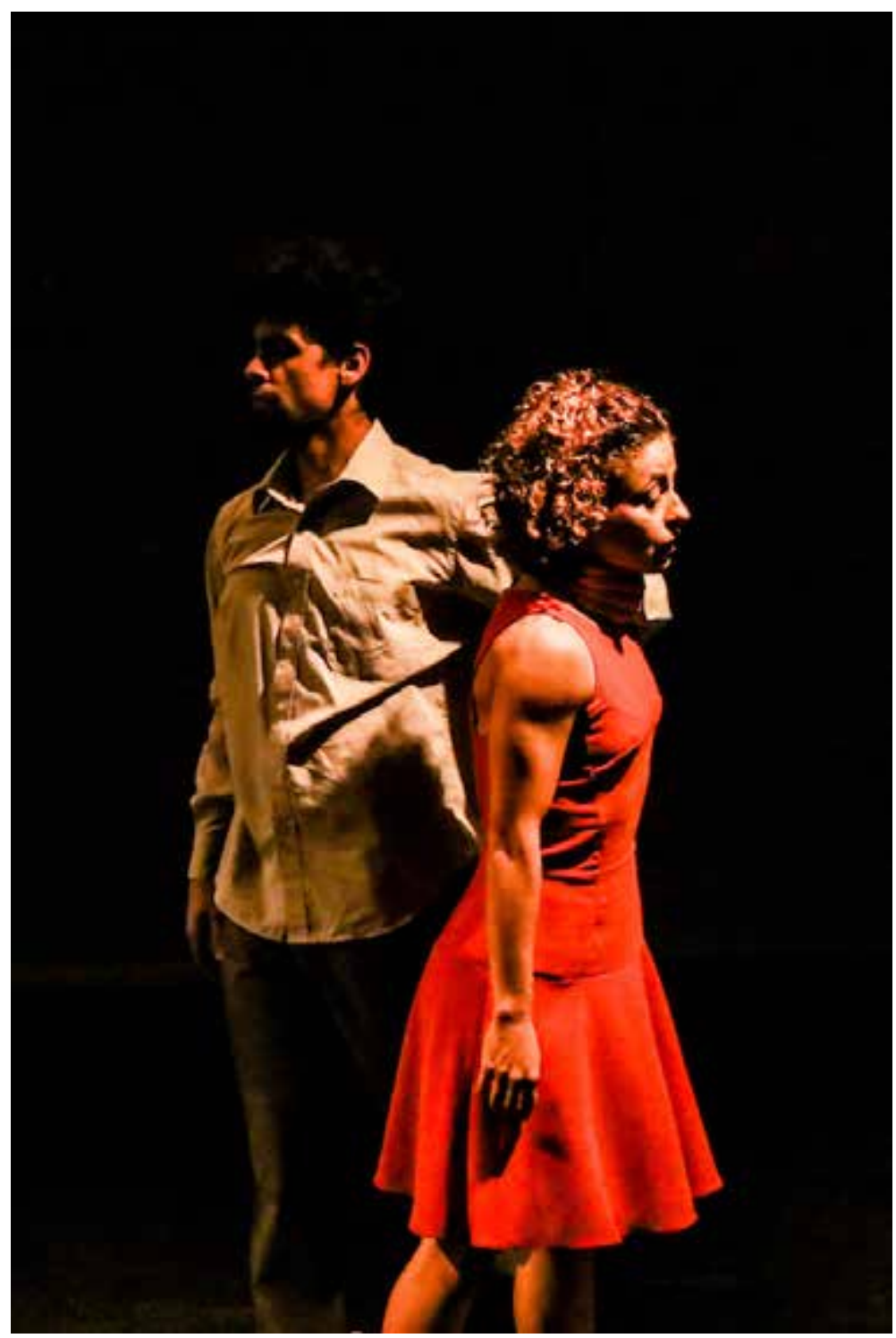

Drico Oliveira e Fernanda Santos em Acuados.

Foto: Raquel Basso (2016)

Em outro momento da coreografia, encontram-se duas mulheres em cena e um homem: a bailarina Fernanda Santos, o bailarino Everon Nunes e a jovem Emily Chagas. Fernanda e Everton aparentam ser um casal, e a bailarina Emily, a filha. A mãe, sob o olhar de testemunha da filha, é lançada em inúmeras direções. Com o domínio técnico dos bailarinos, quase não ouvimos os sons das quedas após os lançamentos. Vemos repetições de corpos femininos sendo arremessados e arrastados pela figura masculina. Nessa cena, fica evidente a violência que acontece não só entre o casal, mas estendida a toda a família. A filha também vive a agressão enquanto "exemplo de amor". Ao final, só com a aproximação da presença masculina, elas já sucumbem e caem. O bailarino Everton, representando o suposto pai ou padrasto, chuta o corpo, no chão, da jovem bailarina negra Emily. Ela permanece em cena, outros bailarinos entram. Na cena, com deslocamentos de grupo, Emily esbarra em vários homens. Eles olham para ela com desprezo, forçando certos esbarrões nos deslocamentos laterais pelo palco até o momento em que ela cai e ali permanece. Há nessa cena uma explícita violência desenhada no detalhe, dada pelos olhares masculinos e pequenos 
gestos. A força da cena também é impactante pelo fato de a jovem bailarina Emily ser negra. Podemos imaginar que essa cena não está nada longe da realidade ${ }^{28}$. Emily resta sozinha no palco, deitada. Logo a seguir, teremos o primeiro solo da coreografia Acuados. Ao som da música, ela se levanta lentamente; seus movimentos são densos, carregados de volume. Apesar da pouca idade da bailarina Emily Chagas, ela expressa o sofrimento da vida e da experiência de violência através de atuação e de seus movimentos. Vemos a extensão de seus braços longe do corpo, que se voltam contra ela própria. Ela se tapeia, incorporando e repetindo na cena ações das quais ela foi vítima, como os golpes na cena anterior. O corpo de Emily se expande na cinesfera e volta repentinamente para o centro, mãos no ventre. Com gestos amplos, ela golpeia a si mesmo. No tapa, ouvimos o som do impacto da mão no rosto. Em meio aos movimentos estilizados da dança, há alguns poucos passos hesitantes. O seu rosto, no final do solo, traz o foco da atenção dos espectadores através de um grito mudo; a bailarina abre sua boca ao máximo, como no grito do quadro de Eduard Munch. Ao final, ela cai, subitamente, como se alguém tivesse tirado sua base, puxado seus pés. O solo da jovem bailarina Emily é carregado de potência, domínio técnico e interpretação intensa na mesma altura do tema tratado. Trata-se de um dos pontos altos da criação.

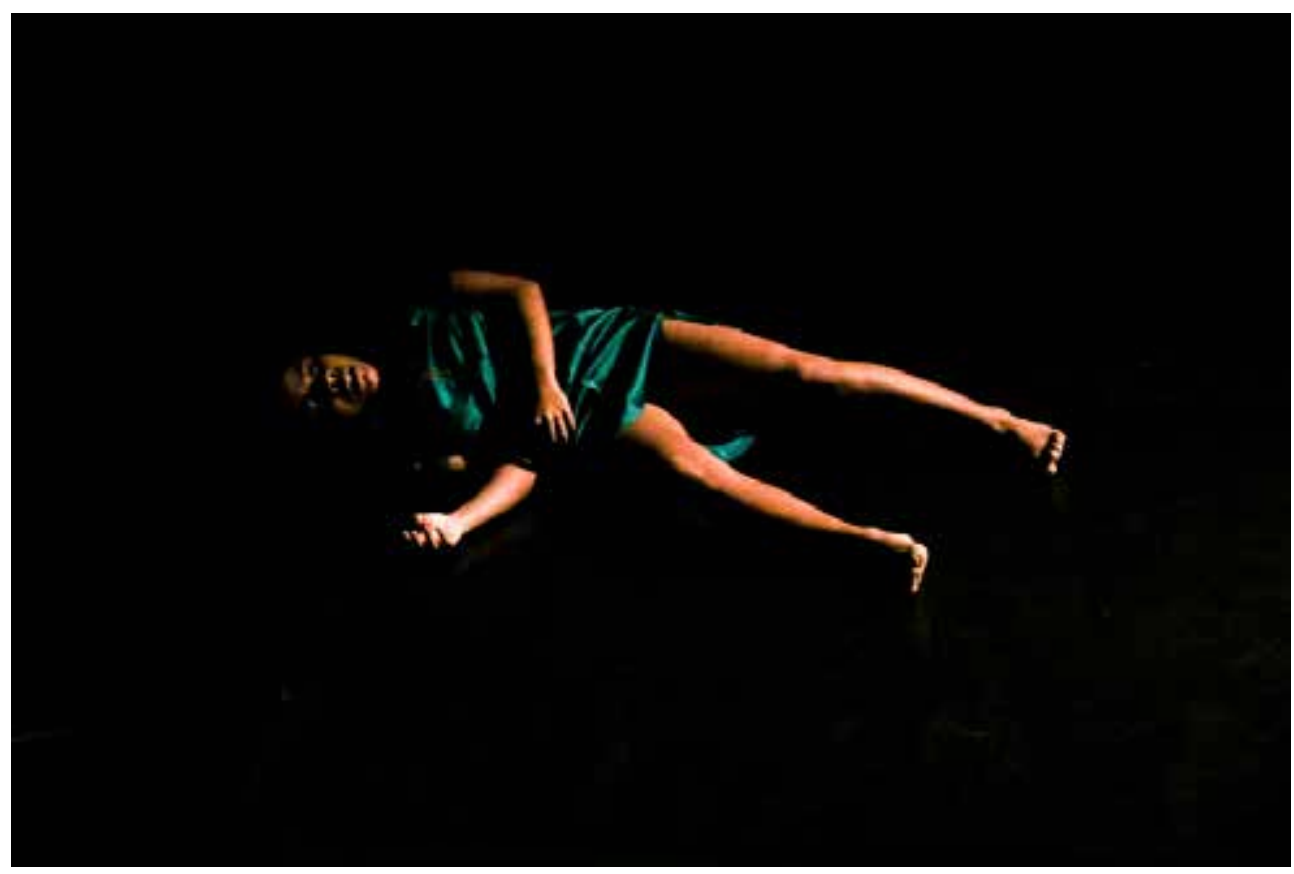

Emily Chagas no único solo do espetáculo Acuados. A imagem do corpo sem o apoio do solo, suspensão da base dos pés; metáfora de um mundo que não dá suporte para o corpo que ela representa, uma jovem mulher negra. Foto: Raquel Basso (2016)

Depois do solo de Emily, segue-se a cena que deu origem ao espetáculo, quando a coreógrafa Eva ainda estava fazendo estudos para a criação. A bailarina Bianca Weber entra pelos fundos do palco, seus olhos estão vendados. Na diagonal de Bianca Weber, o bailarino Drico Oliveira segura um tecido de tafetá branco, que deixa cair, formando uma diagonal em cena. Tateando o espaço com braços

\footnotetext{
${ }^{28}$ Segundo o Mapa da Violência de 2015, houve um aumento de 54\% em assassinato de mulheres negras, ao passo que houve uma diminuição de 9,6\% em relação ao assassinato de mulheres brancas. Isso comprova que, apesar de algumas políticas públicas para as mulheres, elas pouco ou nada atingem as mulheres negras (Ribeiro, 2017).
} 
e pernas, Bianca Weber avança na diagonal do palco caminhando sobre o tecido branco. A vulnerabilidade de sua condição é representada pelos olhos vendados e seus movimentos titubeantes em relação ao espaço. O tecido indica alguma delicadeza dessa condição feminina, e Bianca Weber parece uma mulher em sua noite de núpcias. Ao avançar para o centro do palco, o homem a toca de modo furtivo, inesperado, e ela se assusta. Com os olhos vendados, ela não vê a direção de onde vem os movimentos que a tocam. Ele se aproxima cada vez mais, dançam de modo íntimo, numa dança a dois, de casal. Ele manipula os movimentos de seus braços e, em alguns momentos, ele a alça do chão. As suspensões são fluídas em termos de movimento. Há uma quebra abrupta, quando em uma das suspensões ele a deixa propositalmente cair e, em seguida, joga seu corpo sobre o corpo da bailarina que ainda está se recompondo da queda. Nesse encontro de corpos, há a simulação de uma cena de sexo rápido e abrupto. Ao som de uma ópera, ouvimos as palavras: "doce delícia". A ironia é explícita. Depois do "sexo", cada um se vira para um lado diferente. Em seguida, como uma boneca, ele a manipula. Em um momento de raiva, ela tira a venda de seus olhos, empurra-o e estapeia o corpo do agressor. Há, nesse final de cena, menos movimentos estilizados de dança e as ações de empurrar e bater por parte de Bianca Weber são intensas. Ela coloca a venda nos olhos dele e sai de cena. Afinal, todos estão presos em papéis sociais, reproduzindo as performances de gênero perpetuadas pelas estruturas sociais e interpretadas de distintas maneiras, sobrevivendo ao tempo e ao cristal do patriarcado (Segato, 2017).

Para o senso comum, a sexualidade é tida como algo "natural", algo dado pela natureza. No entanto, a sexualidade envolve rituais, linguagens, fantasias, representações, convenções etc, que são resultados de processos culturais, históricos, e de relações sociais (Louro, 2000). Para Butler (2017) e Bento (2003), a performance de gênero se dá pela repetição de atos, gestos e ações determinados pela cultura na construção do que seriam os ideais de feminino e masculino segundo as noções associadas à heteronormatividade. Conforme Bento (2003), a cirurgia cultural é feita antes de nascermos: basta o médico identificar na barriga da mãe a genitália da criança para que o universo dessa criança seja já projetado na cor rosa ou azul, e consequentemente seus efeitos. Conforme a autora, não existem corpos livres de expectativas ou investimentos sociais. Nossos corpos são violentamente moldados pelos processos sociais, históricos e culturais: corpo-homem, corpo-mulher.

\section{As noivinhas de Acuados}

Na próxima cena do espetáculo, vemos três mulheres com grinaldas na cabeça. As mulheres estão usando os mesmos vestidos coloridos que vestem ao longo do espetáculo, com a diferença da grinalda na cabeça. São as noivinhas. O sonho de conseguir um príncipe persegue o imaginário feminino, e é disso que trata a cena. Em oposição ao grupo formado por três mulheres, temos os noivos com seus buquês de papel, temporários. Há um certo humor nessa cena. De um lado, as três mulheres juntas, com certos trejeitos e frenesis, uma excitação palpitante, elétrica e infantil mostrada através de movimentos que escapam pela periferia dos corpos. Há por parte delas, um rápido e minúsculo movimento de mexer a cabeça. Elas disputam a 
frente do grupo, trocando de lugar repentinamente, eventualmente escapando um movimento, como se fosse involuntário, descontrolado. Elas deixam escapar alguns risos que se dirigem para o outro lado da cena. Os homens, por sua vez, inflamados de uma certa amabilidade e sedução, são os elegidos. Ao se aproximarem deles, elas compreendem que o buquê não é acessível, os homens os suspendem, girando, esquivando-se. Elas correm em busca do buquê com certo desespero e tentativa de autocontrole. Quando os homens pausam e colocam o buquê em frente às mulheres, o buquê logo se desfaz, são pequenas folhas de papel que os homens deixam cair, jogam no chão e nos rostos das mulheres. A mulher, na sociedade, ao longo dos tempos, foi severamente modelada para a figura de esposa, de moça de família. Na maioria das vezes, a mulher entrava no casamento sem mesmo conhecer o seu próprio corpo - o que dirá a sexualidade. Assim, a mulher encontrava-se no casamento em grande desvantagem frente ao homem, que era incentivado a iniciar sua vida sexual antes do casamento. Hoje, a situação é parcialmente diferente, mas as desigualdades sobre a liberdade sexual ainda continuam, como é possível verificar nas redes e manifestações sociais.

As mulheres que se revelam em Acuados têm suas movimentações e ações muitas vezes restringidas; seus corpos são arremessados ora com fluidez, ora com quebras abruptas e inesperadas, revelando um discurso do corpo que enfatiza a dinâmica da vulnerabilidade das mulheres em suas vidas sociais. Ao mesmo tempo, em termos de técnicas de dança contemporânea, esses jogos de suspensão e diferentes modos de lidar com o peso dos corpos revelam domínio de técnicas corporais elaboradas pela coreógrafa e seus experientes intérpretes-criadores. Outro elemento de destaque em termos de discurso do corpo é que a coreografia Acuados apresenta a performance de gênero de mulheres e de homens dentro das lentes do patriarcado e suas estruturas sociais, que repetem o poder e o controle sobre o corpo da mulher.

A antropóloga pesquisadora Rita Segato (2017), que fez inúmeras entrevistas em prisões no Brasil, alega que, conforme sua pesquisa de fundo etnográfico, baseada nos relatos dos agressores, os atos de violência cometidos por esses indivíduos pertencem a um certo mandato, surgem da necessidade de provar algo relacionado à espetacularização da capacidade de controle sobre o corpo da mulher. Esse controle sobre o corpo da mulher tem o intuito de fazê-los parte de um certo imaginário social, que a autora nomeia como a corporação masculina. Para Segato (2017), há na conduta do agressor masculino uma conduta disciplinar, de colocar a vítima no seu lugar de obediência.

Ainda segundo a autora (2017), nós, mulheres, "não somos apenas pessoas e não somos plenamente: somos seres obedientes à pessoa plena que é o sujeito masculino" (Segato, 2012, p. 19). Exemplo disso é que, quando uma mulher faz uma denúncia de abuso, esse é um momento em que a desconfiança moral nos tribunais é um peso, um esforço performativo de gênero pelo qual o homem não precisa passar. Ou seja, na sociedade, de modo geral, a credibilidade dada ao homem é muito maior do que a que é dada à mulher. No que se refere à família, Bento (2012) acredita que, embora haja uma idealização da família brasileira, composta por pai, mãe, filhos e filhas, essa estrutura vem mudando nos últimos tempos. A família tradicional nuclear é apenas uma entre tantas possibilidades de organização, nas últimas décadas outros modelos de família vêm se legitimando e adquirindo respeitabilidade. 
Ao final de Acuados, as mulheres estão sozinhas em cena. Elas não têm mais seus homens "desejados" ou "agressores", nem estão mais acossadas por suas presenças. As paredes que, em muitos momentos dividiam o palco, nessa cena final não estão mais configuradas. Lado a lado, as três mulheres tentam correr para a frente do palco, em direção ao público. No entanto, elas estão presas por um dos pés. Há uma tornozeleira de elástico, em um de seus pés, que não as deixa ir muito longe. A tornozeleira limita o deslocamento de seus corpos e indica que, de algum modo, elas ainda estão presas, talvez ligadas ao vínculo familiar ou matrimonial. Depois de inúmeras tentativas, elas desistem e se dirigem ao fundo do palco. De costas para o público, elas permanecem alguns instantes sentadas, com pequenos movimentos de braços. Ao se virarem para a plateia, seus rostos estão riscados de batom vermelho, em suas mãos há um bolo de fotos de família, que elas lançam aos ares, longe, em direção ao público. São fotos de outras mulheres e de outras famílias. Esse ato de lançar as fotos de suas famílias, ou o próprio fato de lançar fotos - que podem ser lidas como signos de memórias -, remete à metáfora de que, para libertar-se da condição da violência doméstica, há que se abrir mão da família construída, ao longo da civilização, de modo injusto e desproporcional em relação à mulher.

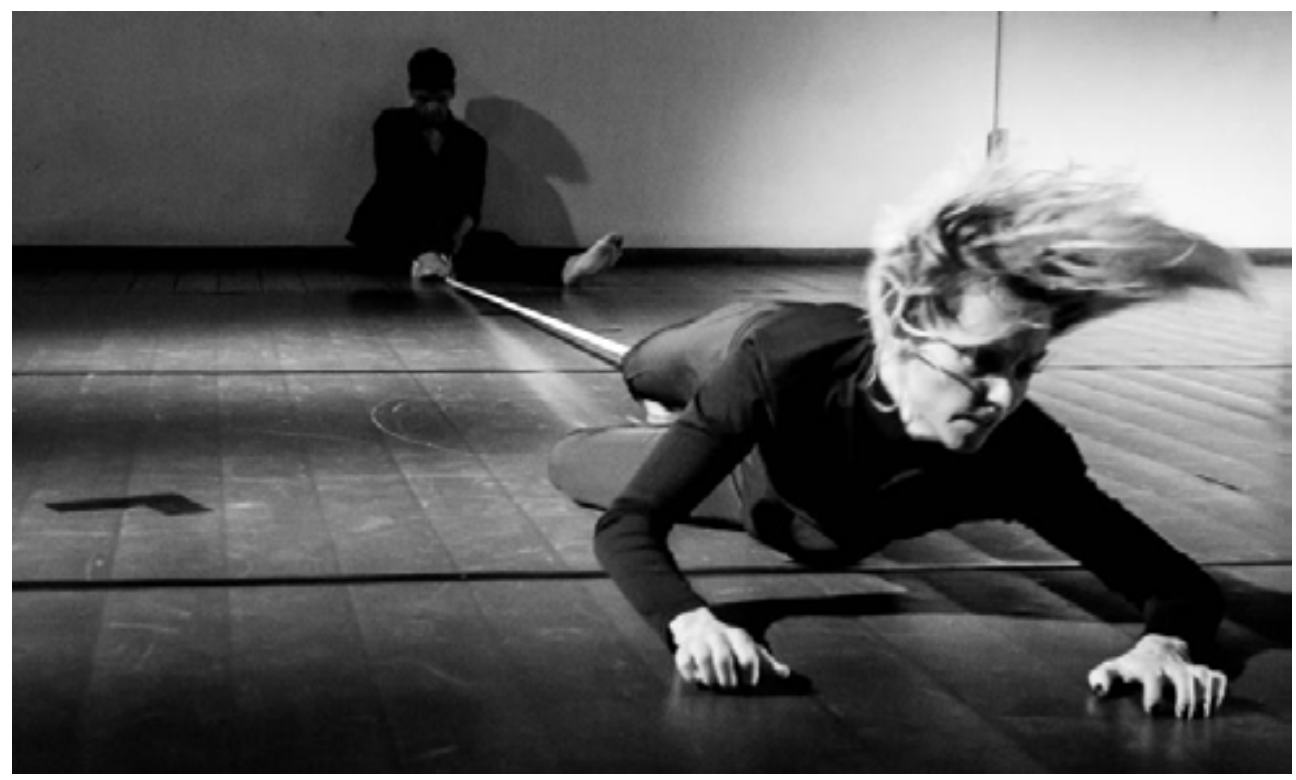

Drico Oliveira e Bianca Weber. O pé preso da bailarina pode indicar a ligação com o passado de violência e de opressão vivida pela sua personagem. A ação também indica sua busca de libertação apesar das amarras sociais e afetivas. Foto: Raquel Basso (2016).

\section{Considerações finais}

É necessário que mulheres e homens libertem-se de papéis que reproduzem e perpetuam o poder do patriarcado. Segato (2017) acredita que a violência masculina extrema é um sintoma da precariedade da vida, das instituições, das leis. Segundo ela, o mandato da masculinidade intensificou-se através da violência pela precariedade da vida. A autora aponta a concentração da riqueza e o colapso da política entre as consequências do que ela intitula de uma re-feudalização do mundo. A coreografia Acuados busca mostrar as diferentes faces do cristal do patriarcado a partir de cenas que mostram a obstinação dos requintes de violência investidos no corpo da mulher. Em Acuados, os elementos cênicos, como as amarras, as vendas, o tule pelo chão, 
são objetos que indicam uma mistura de vulnerabilidade e romantismo em meio a violência, como um sonho dilacerado. As mesas, cadeiras e paredes são signos diretos de onde a violência extrema contra a mulher é, em grande parte, realizada, no lar. As coerências dos gestos produzidos pelas bailarinas e bailarinos servem como denúncia dos atos performativos de gênero, fabricados ao longo da civilização em nome da família patriarcal, calcada na desigualdade de poderes em detrimento das mulheres. O tema escolhido para a Ânima Cia de Dança comemorar seus 25 anos vai de encontro ao estômago do espectador, como um golpe. Para os bailarinos, também não é um tema fácil de incorporar. Como produzir, expressar, representar e dançar movimentos que denunciam a violência contra a mulher com uma noção crítica em relação a esses gestos?

Entre as artes, a dança, enquanto campo social e mercado de trabalho, destaca-se por abrigar uma grande quantidade de mulheres que se distinguem em termos de visibilidade e legitimidade, ainda que essa distinção seja mais simbólica do que econômica, e muitas vezes no interior do próprio campo. Nesses tempos medievais, em que há uma grande censura em direção às artes como um todo, venhamos reavaliar as conquistas feministas e difundir o quanto ainda temos que lutar, mulheres e homens. Eva Schul, enquanto ser humano que sobreviveu aos resquícios da Segunda Guerra Mundial, segue, aos setenta anos, produzindo e denunciando, através de sua condição de artista, mulher, mãe, avó, na resistência frente aos desgovernos e junto à cultura, às artes.

\author{
Sobrevivi ao holocausto e me fiz humana \\ Sobrevivi a repressão e me fiz artista \\ Hoje morro todos os dias esmagada pela desconsideração \\ Ódio, ganância, racismo, homofobia, desgoverno \\ Só me resta dançar, dançar até o meu último suspiro. (Schul, 2017)
}

\title{
Referências
}

BANES, Sally. Spontaneous combustion. In: ALBRIGHT, Ann Copper; GERE, David (Eds.). Taken by Surprise - a dance improvisation reader. Hanover: Wesleyan University Press, 2003. p. 77-88.

BANES, Sally. Terpsichore in Sneakers - post-modern dance. Boston: Houghton Mifflin Company, 1980.

BASSO, Raquel. Acuados: fotografias. Porto Alegre: [S.l.], 2016.

BENTO, Berenice. Transexuais, corpos e próteses. Labrys: Estudos Feministas, Florianópolis, n. 4, ago./dez. 2003. Disponível em: <http://www.tanianavarroswain. com. br/labrys/labrys4/textos/berenice2mf.htm>. Acesso em: 28 mar. 2018.

As famílias que habitam as famílias. Sociedade e Cultura, UFMG, Minas Gerais, v. 15, n. 2, 2012. Disponível em: <https://www.revistas.ufg.br/fchf/issue/view/1245>. Acesso em: 28 mar. 2018. 
CARNEIRO, Maria Elisabeth Ribeiro Carneiro. Feminismo-femisnos. In: COLLING, Ana Maria; TEDESCHI, Losandro Leandro. (Org.). Dicionário Crítico de Gênero. Dourados, MS: Ed. UFGD, 2015.

CARLSON, Marvin. Peformance: uma introdução crítica. Belo Horizonte: Editora UFMG, 2009.

DANTAS, Mônica Fagundes. Desejos de memória: procedimentos de recriação de coreografias de Eva Schul. Cena, v. 2, n. 11, p. 1-24, 2012.

DANTAS, Mônica. Eva Schul: uma vida para reinventar a dança moderna e contemporânea. In: SÃO PAULO. SECRETARIA DE CULTURA. Figuras da Dança: Eva Schul. São Paulo: Governo do Estado de SP, 2013.

DEL PRIORE, Mary. Histórias e conversas de mulher. São Paulo: Planeta do Brasil, 2013.

DESTINO dança Brasil - Porto Alegre. Eva Schul e Eduardo Severino. Apresentação: Deborah Colker. Direção: Pedro Flores da Cunha. Produção Executiva: Bia Flores. Porto Alegre: Canal Brasil, 2014.

FACES|TVE: Eva Schul. Apresentação: Lena Kurtz. Produção executiva: Sílvia Dinelli. Edição e finalização: Álvaro Cardoso. Porto Alegre: TVE, 2016. Disponível em: <https:// www.youtube.com/watch?v=2xokA5GJnJo>. Acesso em: 26 de agosto 2018.

FIGURAS da Dança: Eva Schul. Direção: Inês Bogéa. Produção: Marcio Branco. Realização: São Paulo Companhia de Dança. São Paulo: Ambrogi Produções Cinematográficas, 2013. 1 DVD.

FUNARTE. Brasil Memória das Artes. Navalha na Carne, 1967. Acervo CEDOC/Funarte. In: TAVARES, Joana Ribeiro da Silva. Klauss Vianna, do coreógrafo ao diretor. São Paulo: Annablume, 2010.

GOLDBERG, Roselee. A arte da performance: do futurismo ao presente. São Paulo: Martins Fontes, 2006.

NOGUEIRA, Conceição. Feminismo e Discurso do Gênero na Psicologia Social. Psicologia \& Sociedade, n. 13, v. 1, p. 107-128. São Paulo: Abrapso, 2001.

O OLHAR na dança: Eva Schul. Direção Geral e Coord. de Pesquisa: Juana Miranda. Produtor executivo: Maurício Amaral. Coordenadora Administrativa: Valéria Marcondes. Brasília, DF: Chang, Gestão, Marketing e Produção, 2018. Disponível em: <http://www.oolharnadanca.com.br/>. Acesso em: 26 de agosto de 2018.

RIBEIRO, Djamila. O que é lugar de fala. Belo Horizonte: Letramento, 2017. 
ROMANO, Lúcia. A preparação corporal tem genêro? In TAVARES, Joana Ribeiro da Silva; KEISERMAN, Nara (Org.) O corpo cênico entre o teatro e a dança. São Paulo: Annablume Editora Comunicação, 102-111. 2013.

ROMANO, Lúcia. De quem é esse corpo? A performatividade do feminino no teatro contemporâneo. São Paulo: USP - Departamento de Artes Cênicas/Escola de Comunicações e Artes. Tese de Doutorado, 2009.

SEGATO, Rita Laura. Gênero e colonialidade: em busca de chaves de leitura e de um vocabulário estratégico descolonial. E-cadernos ces, online no dia 01 dezembro 2012. Disponível em: <http://journals.openedition.org/eces/1533>. Acesso em: 30 mar. 2018.

SCHUL, Eva. Discurso proferido em ocasião do Lançamento do Projeto Carne Digital: Acervo Eva Schul em 18 de setembro de 2018. Porto Alegre: [S.l.], 2018a.

SCHUL, Eva. Entrevista concedida a Suzane Weber da Silva em 15 de agosto de 2018. Porto Alegre: [S.l.], 2018b.

SCHUL, Eva. Programa Acuados. Porto Alegre: [S.l.: s.n.], 2016.

SCHUL, Eva. Discurso proferido no prêmio recebido pelo evento Gestos Contemporâneos no Teatro São Pedro de Porto Alegre em 25 de novembro de 2017.

TAVARES, Joana Ribeiro da Silva. Klauss Vianna, do coreógrafo ao diretor. São Paulo: Annablume, 2010.

UTZ, Natália. Acuados: fotografia do registro em vídeo. Porto Alegre: [S.l.], 2016.

Recebido em: 26/09/2018

Aprovado em: 27/10/2018 